\title{
PtRu/C Electrocatalysts Prepared Using Electron Beam Irradiation
}

\author{
Dionísio Furtunato da Silva, Almir Oliveira Neto, Eddy Segura Pino, \\ Michele Brandalise, Marcelo Linardi, Estevam Vitorio Spinacé* \\ Instituto de Pesquisas Energéticas e Nucleares - IPEN/CNEN-SP, \\ Av. Professor Lineu Prestes, 2242, Cidade Universitária, 05508-000 São Paulo - SP, Brazil
}

Received: March 14, 2007; Revised: September 18, 2007

\begin{abstract}
$\mathrm{PtRu} / \mathrm{C}$ electrocatalysts (carbon-supported PtRu nanoparticles) were prepared submitting water/ethylene glycol mixtures containing $\mathrm{Pt}(\mathrm{IV})$ and $\mathrm{Ru}(\mathrm{III})$ ions and the carbon support to electron beam irradiation. The electrocatalysts were characterized by energy dispersive $\mathrm{X}$ ray analysis (EDX), X ray diffraction (XRD) and cyclic voltammetry and tested for methanol electro-oxidation aiming fuel cell application. The obtained PtRu/C electrocatalysts showed superior performance for methanol electro-oxidation at room temperature compared to commercial PtRu/C electrocatalyst.
\end{abstract}

Keywords: PtRu/C electrocatalyst, electron-beam, methanol, fuel cell

\section{Introduction}

Fuel cells convert chemical energy directly into electrical energy with high efficiency, low emission of pollutants and are extremely attractive as power sources for mobile, stationary and portable applications. In the proton exchange membrane fuel cell (PEMFC) the anodic oxidation of hydrogen and the cathodic reduction of oxygen should be catalyzed to occur at adequate rates at low temperatures ${ }^{1-4}$. Carbon-supported platinum or platinum-based nanoparticles are the best electrocatalysts for anodic and cathodic reactions. However, the use of hydrogen as combustible continues to present problems especially for mobile and portable applications $s^{4,5}$. Thus, there has been an increasing interest in the use of alcohols directly as combustible (Direct Alcohol Fuel Cell - DAFC). Methanol has been considered the most promising alcohol and carbon-supported PtRu nanoparticles $\left(\mathrm{PtRu} / \mathrm{C}\right.$ electrocatalyst) the best electrocatalyst $\mathrm{t}^{6-8}$. The catalytic activity of $\mathrm{PtRu} / \mathrm{C}$ electrocatalysts is strongly dependent on the method of preparation and it is one of the major topics studied in Direct Methanol Fuel Cell (DMFC) $)^{9,10}$.

Recently, Spinacé et al. ${ }^{11}$ prepared in a single step carbonsupported PtRu nanoparticles submitting water/2-propanol solutions containing $\mathrm{Pt}(\mathrm{IV})$ and $\mathrm{Ru}(\mathrm{III})$ ions and the carbon support to $\gamma$-irradiation. After 6 hours of irradiation (total dose $3 \mathrm{kGy}$ ) all of the $\mathrm{Pt}(\mathrm{IV})$ and $\mathrm{Ru}(\mathrm{III})$ ions were reduced and deposited on the carbon support. However, the obtained PtRu/C electrocatalysts showed inferior performance compared to commercial PtRu/C E-TEK, which is considered as reference for methanol electro-oxidation ${ }^{9}$. This inferior performance was attributed principally due to fact that the obtained $\mathrm{PtRu}$ nanoparticles have their surfaces enriched in $\mathrm{Ru}$ atoms ${ }^{11,12}$. On the other hand, $\mathrm{PtRu} / \mathrm{C}$ electrocatalysts with superior performance of the commercial PtRu/C electrocatalyst were prepared submitting water/ethylene glycol solutions containing the metal ions and the carbon support to $\gamma$-irradiation, however, the time necessary to reduce the metal ions increased and not all of the $\mathrm{Ru}(\mathrm{III})$ ions were reduced even if a total dose of $48 \mathrm{kGy}$ was applied ${ }^{11,12}$.

In this work, PtRu/C electrocatalysts were prepared in water/ ethylene glycol reaction medium using electron beam irradiation, which permits high dose (kGy) within a few minutes. The obtained $\mathrm{PtRu} / \mathrm{C}$ electrocatalysts were tested for methanol electro-oxidation aiming fuel cell application.

\section{Experimental}

PtRu/C electrocatalysts (20 wt. (\%), Pt:Ru atomic ratio of 50:50) were prepared using $\mathrm{H}_{2} \mathrm{PtCl}_{6} \cdot 6 \mathrm{H}_{2} \mathrm{O}$ (Aldrich) and $\mathrm{RuCl}_{3} \cdot 1.5 \mathrm{H}_{2} \mathrm{O}$ (Aldrich) as metal sources, which were dissolved in water/ethylene

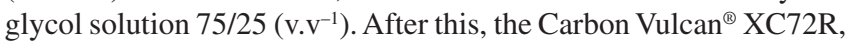
used as support, was dispersed in the solution using an ultrasonic bath. The resulting mixture was submitted under stirring to electron beam source (Electron Accelerator's Dynamitron Job 188 - IPEN/CNEN SP) and the total dose varied between 144 and $432 \mathrm{kGy}$. After irradiation the mixture was filtered and the solid (PtRu/C electrocatalyst) was washed with water and dried at $70{ }^{\circ} \mathrm{C}$ for 2 hours ${ }^{11-13}$.

The Pt:Ru atomic ratios were obtained by EDX analysis using a Philips XL30 scanning electron microscope with a $20 \mathrm{keV}$ electron beam and provided with EDAX DX-4 microanaliser.

The XRD analyses were performed using a Rigaku diffractometer model Multiflex with a $\mathrm{CuK} \alpha$ radiation source. The measured angle range extended from $20^{\circ}$ to $90^{\circ}$ with a scanning rate of $2^{\circ}$ per minute. The average crystallite size was calculated using Scherrer equation $^{14}$.

Electrochemical studies of the electrocatalysts were carried out using the thin porous coating technique ${ }^{15}$. An amount of $20 \mathrm{mg}$ of the electrocatalyst was added to a solution of $50 \mathrm{~mL}$ of water containing 3 drops of a $6 \%$ polytetrafluoroethylene (PTFE) suspension. The resulting mixture was treated in an ultrasound bath for 10 minutes, filtered and transferred to the cavity $\left(0.30 \mathrm{~mm}\right.$ deep and $0.36 \mathrm{~cm}^{2}$ area) of the working electrode. The quantity of electrocatalyst in the working electrode was determined with a precision of $0.0001 \mathrm{~g}$. In cyclic voltammetry experiments the current values (I) were expressed in amperes and were normalized per gram of platinum $\left(\mathrm{A}_{\mathrm{pt}^{-1}}\right)$. The quantity of platinum was calculated considering the mass of the electrocatalyst present in the working electrode multiplied by its percentage of platinum. The reference electrode was a RHE and the counter electrode was a platinized Pt plate. Electrochemical measurements were made using a Microquimica (model MQPG01, Brazil) potentiostat/galvanostat coupled to a personal computer and using the Microquimica software. Cyclic Voltammetry was performed in a 0.5 mol. $\mathrm{L}^{-1} \mathrm{H}_{2} \mathrm{SO}_{4}$ solution saturated with $\mathrm{N}_{2}$. The evaluation of methanol oxidation was performed at $25{ }^{\circ} \mathrm{C}$ using $0.1,0.5$ and 1.0 mol. $\mathrm{L}^{-1}$ of methanol in $0.5 \mathrm{~mol} . \mathrm{L}^{-1} \mathrm{H}_{2} \mathrm{SO}_{4}$. Chronoamperom- 
etry experiments were performed using 1.0 mol.L $\mathrm{L}^{-1}$ of methanol in $0.5 \mathrm{~mol} . \mathrm{L}^{-1} \mathrm{H}_{2} \mathrm{SO}_{4}$ at $0.5 \mathrm{~V}$ and at room temperature. For comparative purposes a commercial PtRu/C E-TEK (20 wt. (\%), Pt:Ru molar ratio 50:50, Lot \# B0011117) was used.

\section{Results and Discussion}

$\mathrm{PtRu} / \mathrm{C}$ electrocatalysts were prepared by simultaneous reduction of $\mathrm{Pt}(\mathrm{IV})$ and $\mathrm{Ru}(\mathrm{III})$ ions in the presence of the carbon support using water/ethylene glycol solution as reaction medium. The resulting mixture was submitted to electron beam irradiation, which causes the ionization and excitation of water forming the species showed in Equation $1^{16}$.

$$
\mathrm{H}_{2} \mathrm{O} \rightarrow \mathrm{e}_{\mathrm{aq}}{ }^{-}, \mathrm{H}^{+}, \mathrm{H}, \mathrm{OH}, \mathrm{H}_{2} \mathrm{O}_{2}, \mathrm{H}_{2}
$$

The solvated electrons, $\mathrm{e}_{\mathrm{aq}}$, and $\mathrm{H}$. atoms are strong reducing agents and reduce metal ions down to the zero-valent state (Equation 2 and 3)

$$
\begin{aligned}
& \mathrm{M}^{+}+\mathrm{e}_{\mathrm{aq}}^{-} \rightarrow \mathrm{M}^{0} \\
& \mathrm{M}^{+}+\mathrm{H} \rightarrow \mathrm{M}^{0}+\mathrm{H}^{+}
\end{aligned}
$$

Similarly, multivalent ions, like $\mathrm{Pt}(\mathrm{IV})$ and $\mathrm{Ru}(\mathrm{III})$, are reduced by multistep reactions. On the other hand, $\mathrm{OH}$ radicals could oxidize the ions or the atoms into a higher oxidation state and thus to counterbalance the reduction reactions (2) and (3). Thus, an $\mathrm{OH}$ radical scavenger is added to the solution, in this case ethylene glycol, which reacts with these radicals leading to the formation of radicals exhibiting reducing power that are able to reduce metal ions (Equation 4 and 5) ${ }^{16,17}$.

$$
\begin{aligned}
& \left(\mathrm{CH}_{2} \mathrm{OH}\right)_{2}+\cdot \mathrm{OH} \rightarrow \mathrm{HOH}_{2} \mathrm{CC} H O H+\mathrm{H}_{2} \mathrm{O} \\
& \mathrm{M}^{+}+\mathrm{HOH}_{2} \mathrm{CC} H O H \rightarrow \mathrm{M}^{0}+\mathrm{HOH}_{2} \mathrm{CCHO}+\mathrm{H}^{+}
\end{aligned}
$$

In this manner, the atoms produced by the reduction of metals ions progressively coalesce leading to the formation of carbon-supported $\mathrm{PtRu}$ nanoparticles (PtRu/C electrocatalyst).

In the preparation of $\mathrm{PtRu} / \mathrm{C}$ electrocatalysts water/ethylene glycol solutions containing $\mathrm{Pt}(\mathrm{IV})$ and $\mathrm{Ru}(\mathrm{III})$ ions showed a dark brown color before the addition of the carbon support and irradiation. After irradiation and separation of the solid (PtRu/C electrocatalyst) by filtration, the reaction medium becomes colorless when a total reduction of $\mathrm{Pt}(\mathrm{IV})$ and $\mathrm{Ru}(\mathrm{III})$ ions occurs. A total reduction of metal ions was observed for $\mathrm{PtRu} / \mathrm{C}$ electrocatalysts prepared using $\gamma$-irradiation and water/2-propanol as reaction medium after 6 hours of irradiation time (total dose of $3 \mathrm{kGy})^{11,12}$. The influence of irradiation time on the preparation of $\mathrm{PtRu} / \mathrm{C}$ electrocatalysts using electron beam is shown in Table 1. In all experiments the reaction media remained colored after electro beam irradiation suggesting that the complete reduction of the metallic ions was not occurred even if a total dose of $432 \mathrm{kGy}$ was applied. For all samples, Pt:Ru atomic ratios determined by EDX analysis were approximately 80:20 and were different from nominal Pt:Ru atomic ratios of 50:50 used in the preparations. A qualitative test with potassium iodide ${ }^{18}$ did not detect platinum ions in reaction media, suggesting that only ruthenium ions remained in solution. These results were similar to the ones observed for $\mathrm{PtRu} / \mathrm{C}$ electrocatalysts prepared in water/ethylene glycol media using $\gamma$-irradiation ${ }^{11,12}$.

The $\mathrm{X}$ ray diffractograms of $\mathrm{PtRu} / \mathrm{C}$ electrocatalysts prepared using electron beam irradiation are shown in Figure 1. The diffratograms showed a broad peak at about $25^{\circ}$, which was associated to the Vulcan XC72R support material, and five diffraction peaks at about $2 \theta=40^{\circ}, 47^{\circ}, 67^{\circ}, 82^{\circ}$ e $87^{\circ}$ that are associated to the (111), (200), (220), (311) e (222) planes, respectively, which are characteristic of the fcc structure of platinum and platinum alloys ${ }^{19}$. No peaks, which could be attributed to metallic ruthenium or to materials rich in ruthenium with hexagonal structure, appear in the XRD patterns. On the other hand, the presence of these species as amorphous materials could not be discarded. The (220) reflections of the fcc structure were used to calculate the average crystallite size according to Scherrer formula ${ }^{14}$ and the calculated values were in the range of $2.5-3.5 \mathrm{~nm}$ (Table 1).

The cyclic voltammograms in acid medium of the PtRu/C electrocatalysts prepared using electron beam irradiation and commercial $\mathrm{PtRu} / \mathrm{C}$ electrocatalyst are shown in Figure 2. For commercial PtRu/C electrocatalyst the cyclic voltammogram do not have a well-defined hydrogen adsorption-desorption region $(0-0.4 \mathrm{~V})$ and showed an increase of the current values in the double layer $(0.4-0.8 \mathrm{~V})$, which are attributed to ruthenium oxide species. These features are characteristic of $\mathrm{PtRu} / \mathrm{C}$ electrocatalyst with $\mathrm{Pt}: \mathrm{Ru}$ atomic ratio of 50:50 ${ }^{19-21}$. The cyclic voltammograms of PtRu/C electrocatalysts prepared using electron beam irradiation (Pt:Ru atomic ratio of 80:20) showed the hydrogen adsorption-desorption region more defined than commercial $\mathrm{PtRu} / \mathrm{C}$ electrocatalyst and a decrease in the currents in the double

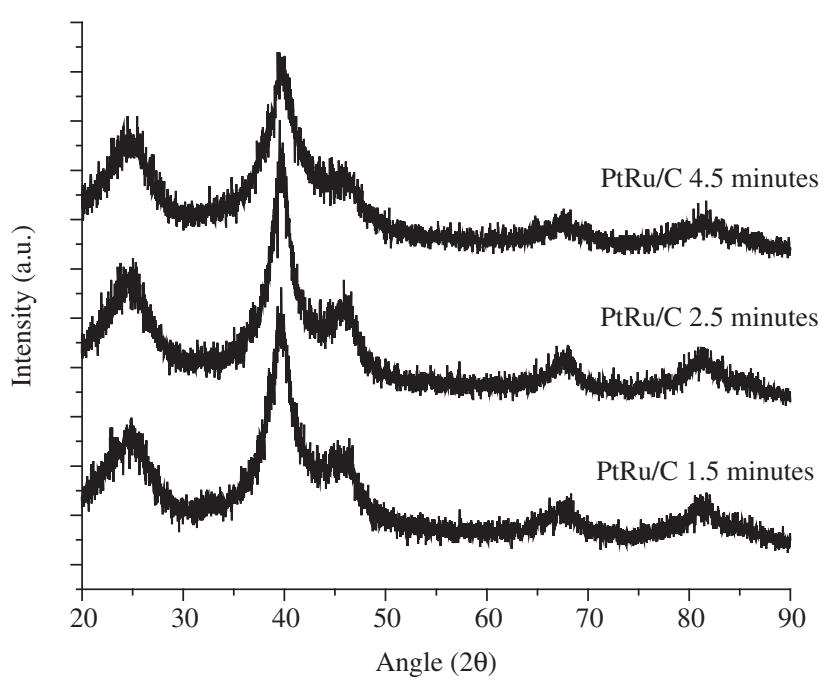

Figure 1. $\mathrm{X}$ ray diffractograms of $\mathrm{PtRu} / \mathrm{C}$ electrocatalysts prepared using electron beam irradiation.

Table 1. Influence of electron beam irradiation time on Pt:Ru atomic ratio and average crystallite size of the PtRu/C electrocatalysts (20 wt. (\%) of metals, nomimal Pt:Ru atomic ratio of 50:50, dose rate $1.6 \mathrm{kGys}^{-1}$ water/ethylene glycol volumetric ratio of 75/25).

\begin{tabular}{ccccc}
\hline $\begin{array}{c}\text { Irradiation time } \\
(\text { minutes })\end{array}$ & $\begin{array}{c}\text { Total dose } \\
(\mathrm{kGy})\end{array}$ & $\begin{array}{c}\text { Color of reaction medium } \\
\text { after electron beam irradiation }\end{array}$ & $\begin{array}{c}\text { Pt:Ru atomic ratio } \\
(\text { EDX) }\end{array}$ & $\begin{array}{c}\text { Crystallite size } \\
(\mathrm{nm})\end{array}$ \\
\hline 1.5 & 144 & Purple & $82: 18$ & 2.9 \\
2.5 & 240 & Brown & $81: 19$ & 3.3 \\
4.5 & 432 & Brown & $83: 17$ & 2.6 \\
\hline
\end{tabular}




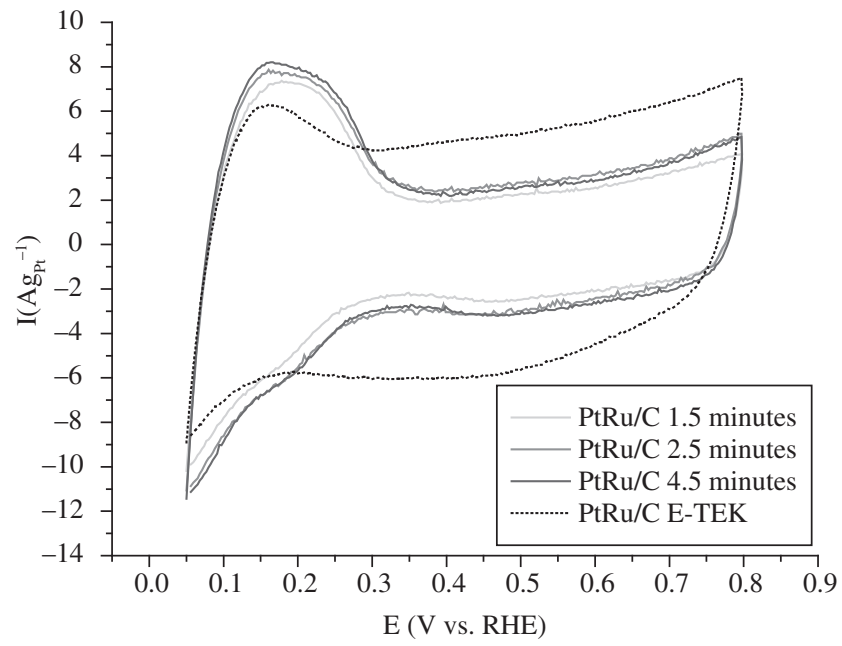

Figure 2. Cyclic Voltammograms of PtRu/C electrocatalysts prepared using electron beam irradiation and commercial PtRu/C electrocatalyst in $0.5 \mathrm{~mol} . \mathrm{L}^{-1}$ $\mathrm{H}_{2} \mathrm{SO}_{4}$ with a sweep rate of $10 \mathrm{mV} \cdot \mathrm{s}^{-1}$.

layer. The form of these voltammograms are in agreement with the relative $\mathrm{Pt}: \mathrm{Ru}$ ratio ${ }^{21}$.

The electro-oxidation of methanol was studied varying the concentration from 0.1 to 1.0 mol.L $\mathrm{L}^{-1}$ (Figure 3 ). In a general manner, for all electrocatalysts, the current values in the hydrogen region $(0-0.4 \mathrm{~V})$ decrease with the increase of methanol concentration. This occurs most likely due to the increase of methanol adsorption on the surface $^{19}$. For potentials more positive than $0.3 \mathrm{~V}$, the current values increase with methanol concentration even for $1.0 \mathrm{~mol} . \mathrm{L}^{-1}$.

In Figure 4 are presented chronoamperometric curves in 1 mol. $\mathrm{L}^{-1}$ methanol in 0.5 mol. $\mathrm{L}^{-1} \mathrm{H}_{2} \mathrm{SO}_{4}$ at $0.5 \mathrm{~V}$ for different electrocatalysts. The currents values were normalized per gram of platinum, considering that methanol adsorption and dehydrogenation occur only on platinum sites at room temperature ${ }^{22,23}$. In all current-time curves there is an initial current drop in the first minutes followed by a slower decay, but the current values obtained for $\mathrm{PtRu} / \mathrm{C}$ electrocatalysts prepared using electron beam irradiation were always higher than those obtained for commercial PtRu/C E-TEK electrocatalyst. It has been described in the literature that $\mathrm{Pt}: \mathrm{Ru}$ atomic ratio influences the performance of the electrocatalysts for methanol electro-oxidation and at room temperature an increase of performance was observed for $\mathrm{PtRu} / \mathrm{C}$ electrocatalysts having a high platinum to ruthenium ratio $^{24,25}$.

\section{Conclusion}

Active PtRu/C electrocatalysts for methanol oxidation were obtained in a single step within few minutes using electron beam irradiation. The obtained Pt:Ru atomic ratios were approximately 80:20, showing that not all of the Ru(III) ions were reduced even if a total dose of $432 \mathrm{kGy}$ was applied. The PtRu/C electrocatalysts showed the typical fcc structure of platinum and platinum alloys with average crystallite sizes of about $3 \mathrm{~nm}$. The obtained PtRu/C electrocatalysts showed superior performance for methanol oxidation at room temperature compared to commercial PtRu/C electrocatalyst. Modifications of experimental procedure in order to prepare PtRu/C electrocatalysts with more ruthenium content and experiments using these electrocatalysts in gas diffusion electrodes for tests in single direct methanol fuel cell are currently in progress.

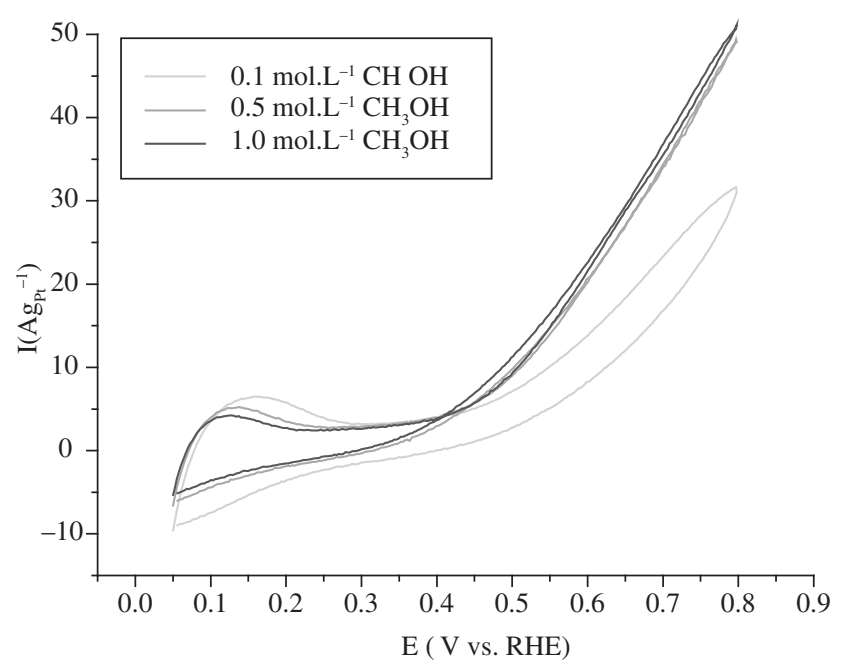

Figure 3. Cyclic voltammograms of $\mathrm{PtRu} / \mathrm{C}$ electrocatalyst prepared using electron beam irradiation (4.5 minutes) in 0.5 mol. $\mathrm{L}^{-1} \mathrm{H}_{2} \mathrm{SO}_{4}$ containing different concentrations of methanol with a sweep rate of $10 \mathrm{mV} \cdot \mathrm{s}^{-1}$.

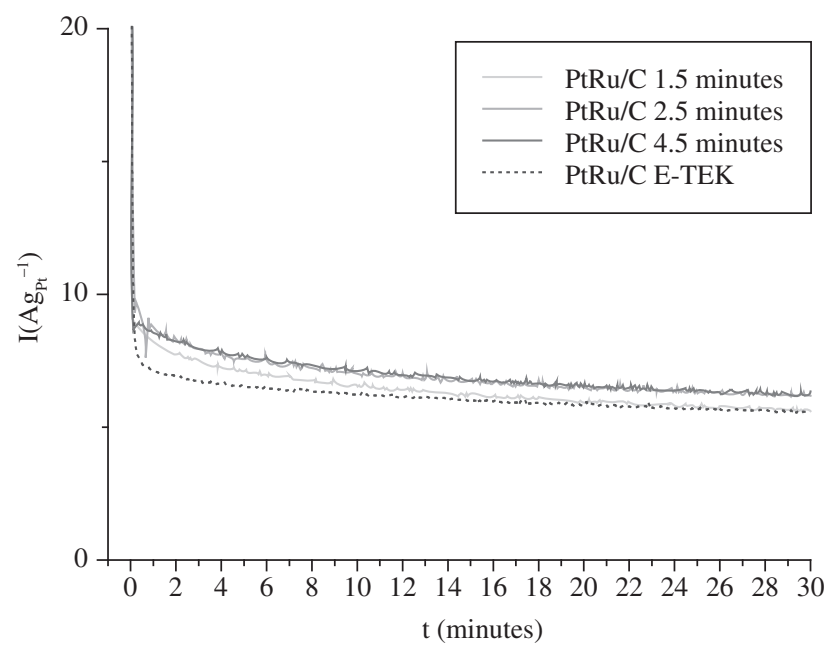

Figure 4. Current-time curves at $0.5 \mathrm{~V}$ for different electrocatalysts in 1.0 mol.L ${ }^{-1}$ methanol in 0.5 mol. $\mathrm{L}^{-1} \mathrm{H}_{2} \mathrm{SO}_{4}$.

\section{Acknowledgments}

The authors thank FAPESP and CNPq for financial support and Elisabeth S.R. Somessari, Carlos Gaia da Silveira, Helio Paes e Samir L. Somessari (CTR - IPEN/CNEN-SP).

\section{References}

1. Wendt H, Gotz W, Linardi M. Tecnologia de Células a Combustível. Química Nova. 2000 Jul-Aug; 23(5):538-546.

2. Gonzalez ER. Eletrocatálise e Poluição Ambiental. Química Nova. 2000 Mar-Apr; 23(5):262-266.

3. Steele BCH, Heinzel A. Materials for fuel-cell technologies. Nature. 2001 Nov; 414(6861):345-352.

4. Carrete L, Friedrich KA, Stimming U. Fuel Cells: Principles, types, fuels, and applications. Physical Chemistry Chemical Physics. 2000 Dec; 1(4):162-193. 
5. Schlapbach L, Zuettel A. Hydrogen-storage materials for mobile applications. Nature. 2001 Nov; 414(6861):353-358.

6. Acres GJK, Frost JC, Hards GA, Potter RJ, Ralph TR, Tompsett D et al. Catalysis Today. 1997 Nov; 38(4):393-400.

7. Wasmus S, Kuver A, Methanol oxidation and direct methanol fuel cell: a selective review. Journal of Electroanalytical Chemistry. 1999 Jan; 461(1-2):14-31

8. Lamy C, Lima A, LeRhun V, Deline F, Coutanceau C, Léger J-M. Recent advances in the development of direct alcohol fuel cells. Journal of Power Sources. 2002 Mar; 105(2):283-296.

9. Spinacé EV, Neto AO, Franco EG, Linardi M, Gonzalez ER. Métodos de preparação de nanopartículas metálicas suportadas em carbono de alta área superficial, como eletrocatalisadores em células a combustível com membrana trocadora de prótons. Química Nova. 2004 Jul-Aug; 27(4):648-654.

10. Liu H, Song C, Zhang L, Zhang J, Wang H, Wilkinson DP. A review of anode catalysis in the direct methanol fuel cell. Journal of Power Sources. 2006 Apr; 155(2):95-110.

11. Spinacé EV, Silva DF, Cruz VA, Neto AO, Machado LDB, Pino ES et al. Preparação de eletrocatalisadores PtRu/C utilizando radiação gama para aplicação como ânodo na oxidação direta de metanol em células a combustível. Anais of the International Nuclear Atlantic Conference -INAC. [CD-ROM]. Santos. 2005 Sep.

12. Silva DF. Preparação de eletrocatalisadores PtRu/C utilizando radiação gama para aplicação como ânodo na oxidação direta de metanol. Dissertação (Mestrado) - Instituto de Pesquisas Energéticas e Nucleares. São Paulo; 2006

13. Spinacé EV, Neto AO, Linardi M, Silva DF, Pino ES, Cruz VA. Processo de preparação de eletrocatalisadores utilizando processos radiolíticos para aplicação em células a combustível com membrana trocadora de prótons. Brazilian Patent INPI - RJ PI0505416-8. 08 Dec. 2005.

14. Radmilovic V, Gasteiger HA, Ross PN. Structure and chemical-composition of a supported Pt-Ru electrocatalyst for methanol oxidation. Journal of Catalysis. 1995 Jun; 154(1):98-106.
15. Neto AO, Giz MJ, Perez J, Ticianelli EA, Gonzalez ER. The electrooxidation of ethanol on Pt-Ru and Pt-Mo particles supported on highsurface-area carbon. Journal of the Electrochemical Society. 2002 Mar; 149(3):A272-A279.

16. Belloni J, Mostafavi M, Remita H, Marignier J-L, Delcourt M-O. Radiation-induced synthesis of mono and multi-metallic clusters and nanocolloids. New Journal of Chemistry. 1998 Nov; 22(11):1239-1255.

17. Soroushian B, Lampre I, Belloni J, Mostafavi M. Radiolysis of silver ion solutions in ethylene glycol: solvated electron and radical scavenging yields. Radiation Physics and Chemistry. 2005 Feb; 72(2-3):111-118.

18. Julsing HG, McCrindle RI. Colorimetric method for the determination of residual Pt in treated acidic effluents. South African Journal of Chemistry. 2000 Sep; 53(2):86-89.

19. Neto AO, Vasconcelos TRR, Silva RWRV, Linardi M, Spinacé EV. Electrooxidation of ethylene glycol on $\mathrm{PtRu} / \mathrm{C}$ and $\mathrm{PtSn} / \mathrm{C}$ electrocatalysts prepared by alcohol-reduction process. Journal of Applied Electrochemistry. 2005 Feb; 35(2): 193-198.

20. Lima RB, Paganin V, Iwasita T, Vielstich W. On the electrocatalysis of ethylene glycol oxidation. Electrochimica Acta. 2003 Dec; 49(1):85-91.

21. Camara GA, de Lima RB, Iwasita T. Catalysis of ethanol electrooxidation by PtRu: the influence of catalyst composition. Electrochemistry Communications. 2004; 6(8):812-815.

22. Gasteiger HA, Markovic N, Ross PN, Carins EJ. Temperature-dependent methanol electrooxidation on well-characterized Pt-Ru alloys. Journal of the Electrochemical Society. 1994 Jul; 141(7):1795-1803.

23. Dubau L, Hahn F, Coutanceau C, Léger J-M, Lamy C. On the structure effects of bimetallic PtRu electrocatalysts towards methanol oxidation. Journal of Electroanalytical Chemistry. 2003 Sep; 554(1):407-415.

24. Dubau L, Coutanceau C, Garnier E, Léger J-M, Lamy C. Electrooxidation of methanol at platinum-ruthenium catalysts prepared from colloidal precursors: Atomic composition and temperature effects. Journal of Applied Electrochemistry. 2003 May; 33(5):419-429.

25. Dickinson AJ, Carrette LPL, Collins JA, Friedrich KA, Stimming U, Performance of Methanol Oxidation Catalysts with Varying Pt:Ru Ratio as a Function of Temperature. Journal of Applied Electrochemistry. 2004 Oct; 34(10):975-980. 